AGRICULTURE AND BIOLOGY JOURNAL OF NORTH AMERICA

ISSN Print: 2151-7517, ISSN Online: 2151-7525, doi:10.5251/abjna.2013.4.3.252.259

(C) 2013, ScienceHu $\beta$, http://www.scihub.org/ABJNA

\title{
The effect of harvesting stage on fruit quality and shelf-life of four tomato cultivars (Lycopersicon esculentum Mill).
}

\author{
${ }^{1}$ Parker. R., B. K. ${ }^{2}$ Maalekuu* \\ ${ }^{2}$ Department of Horticulture, College of Agriculture and Natural Resources, \\ Kwame Nkrumah University of Science and Technology (KNUST), Kumasi. \\ ${ }^{1}$ Ministry of Agriculture, Accra \\ ${ }^{*}$ Corresponding author: kbmaalekuu.agric.@knust.edu.gh
}

\begin{abstract}
After six days of storage at room temperature $\left(24^{\circ} \mathrm{C}\right)$, the effect of harvesting stage on fruit quality and shelf-life of four local cultivars of tomato (Rendo, Petomech, Cocoa and Power) of Lycopersicon esculentum Mill was investigated at the Department of Horticulture, KNUST. The experimental design adopted was a $4 \times 4 \times 2$ factorial split-plot design; representing the four cultivars, four different ripening stages (Mature Green, 50\% ripe, $75 \%$ ripe and $95 \%$ ripe) and two harvest intervals. Three fruit samples of the individual cultivars selected from each plot at the different ripening stages were evaluated for some quality parameters [fruit water loss(WL), fruit fresh weight (FFW), decay, total soluble solids (TSS), dry matter content (RDM), pericarp thickness (PTK), membrane ion leakage (EL) and fruit firmness (FF)]. The results showed that, Rendo at matured green and $50 \%$ ripe stages were outstanding in all the parameters examined, due to its good characteristics such as low water loss, high firmness, low membrane ion leakage and relatively thick pericarp tissue. These results suggest that Rendo could be grown by farmers in even distant areas that have problems with storage facilities, transportation and bad road network since it possesses properties which can prolong its shelf life.
\end{abstract}

Keywords: Rendo, Shelf-life, Fruit quality, Ripening stages, Lycopersicon esculentum.

\section{INTRODUCTION}

Tomato (Lycopersiconesculentum Mill) belongs to the family Solanaceae and originated from Central and South America. The crop was introduced into West Africa in the 16th and 17th centuries by the Portuguese, and it has since become the most popular vegetable crop (Norman, 1992). It has a wide climate tolerance (Purseglove, 1991) that grows between temperatures of $10^{\circ} \mathrm{C}$ to $30^{\circ} \mathrm{C}$ (Messiaen, 1994). It does require a relatively high humidity and longer hours of day light to develop and grow well (Romain, 2011). The best growth medium is a welldrained fertile soils with a good moisture-retaining capacity enriched with high level of organic matter at a pH of 5.8-6.8 (Tindall, 1993). Thus, the crop has different types of growth habits namely; determinate, indeterminate and semi determinate (Norman, 1992).

In Ghana, the crop is regarded as the most important vegetable in terms of production, marketing and consumption (Nkansahet al., 2003). Its production zones cover the Northern and Upper Regions as well as the Southern Volta Region of Ghana. There have been substantially good productions at Akumadan and Wenchi districts. Co-operative tomato growing is however, concentrated at Mankessim, Swedru, Nsawam, Akbako-Hikpo, Amasaman, Mangoase, Sege, Dodowa and Ayikai-Dablo (Norman, 1992).

The tomato fruit is moderately rich in Vitamin $\mathrm{A}$ and $\mathrm{C}$ and contains $93.8 \mathrm{~g}$ water, $1.2 \mathrm{~g}$ protein, $4.8 \mathrm{~g}$ carbohydrate (including $0.7 \mathrm{~g}$ cellulose), $7 \mathrm{mg}$ calcium $0.6 \mathrm{mg}$ ion, $0.5 \mathrm{mg}$ carotene, $0.06 \mathrm{mg}$ thiamine, $0.04 \mathrm{mg}$ riboflavin, $0.6 \mathrm{mg}$ niacin and $23 \mathrm{mg}$ vitamin $\mathrm{C}$ per $100 \mathrm{~g}$. The energy value is $83 \mathrm{KJ}$ (or $20 \mathrm{Kcal}$ ) $/ 100 \mathrm{~g}$ (Nkansahet al., 2003). In West Africa, tomatoes are mainly used in preparation of stews, soups, and sauces. They are also used raw in salad, canned and made into juices, puree, pickles and other products (Norman, 1992). Tomatoes are an excellent source of lycopene which help protect against and reduce cancer (Giovanucci, 1995). Good fruit quality (size, colour, firmness and nutritive value) is a factor which influences consumers' purchase and consumption (Atherton and Rudich, 1986). However, the quality is compromised when exposure to high temperature, high relative humidity, and poor handling and storage 
practices especially in the tropics leading to high postharvest losses. Carbohydrate content and organic acids (stage of maturity) also affect the quality attributes of the tomato fruit (Norman, 1992).

Kader (1992) estimated a postharvest loss in developing countries to be $20-50 \%$ and Ghana is not exempted. Postharvest loss occurrence in Ghana is often due to long distance between production site and the market centers, condition of roads and inadequate or unavailability of cooling vans for transporting the fruits. Hence, Olympio and Kukuih (2002) suggested that, there was the need to come up with varieties that could withstand the transportation damages or improve the handling ability of varieties grown.

It has become necessary to grow improved varieties and harvest crops at the appropriate physiological maturity stage if postharvest loss in agricultural produce is to be minimized. The aim of this study therefore was to determine the maturity stage of tomato fruit at harvest that will prolong fruit shelf life and quality and also establish association between the various parameters affecting fruit quality and shelf life.

\section{MATERIALS AND METHODS}

Production of fruits: The fruits used for the study (Fruit quality and shelf life studies)were harvested from four tomato cultivars, Power, Petomech, Rendo and Cocoa, which were cultivated in the experimental field of the Department of Horticulture, Kwame Nkrumah University of Science and Technology (KNUST), Kumasi in Ghana to ensure adequacy and avoid bias.

All nursery practices such as weeding, watering, and pricking out were carried out efficiently. Before transplanting of seedlings, the main field was slashed, ploughed, harrowed and then leveled. Seedlings were transplanted onto the field after lining and pegging had been done. Cultural practices such as hoeing or hand picking of weeds, spraying of pesticides and insecticides (Karate at $30 \mathrm{ml} / 15$ । Knapsack) and fungicides (10g of Shavit F 71.5 WP) and staking were carried out when necessary. NPK 15:15:15 compound fertilizer was applied to each plant at the rate of $5 \mathrm{~g}$, in two (2) weeks after transplanting. Two weeks after the NPK application, $5 \mathrm{~g}$ of Sulphate of ammonium was also applied.

The experimental design adopted was a $3 \times 4 \times 4 \times 2$ factorial in a CRBD design. This involved: 4 cultivars used in three blocks; a total of 2 harvesting made in the season (harvest interval); and 4 ripening stages (Mature Green, $50 \%$ ripe, $75 \%$ ripe and $95 \%$ ripe).

Fruits were harvested at four (4) different ripening stages (matured green, $50 \%$ ripe, $75 \%$ ripe and $95 \%$ ripe) and stored in well ventilated room for a period of six (6) days and fruit quality evaluated. A minimum of three (3) fruits per ripening stage were used for the laboratory analysis.

\section{Laboratory Analysis (Fruit quality and shelf life studies)}

Fruit Water Loss (WL): Fruit water loss was determined (at four ripening stages) by weighing fuits daily and the difference in weight loss was expressed as a percentage of weight loss from the initial fruit weight.

Fruit Fresh Weight (FFW): Fruit fresh weight (at the four ripening stages) was measured in grams immediately after the experiment was set up, using an electronic balance.

Decay: Fruits were considered decayed once fungal mycelia appeared on the peel or calyx. Decay is expressed as a percentage of the total initial fruit number.

Total Soluble Solids (TSS): Total soluble solids were determined using the same fruits tested for water loss, using Atago Handheld Refractometer in Brix ${ }^{\circ}$, (Basset, 1986).

Dry Matter Content (RDM): Dry matter content was also measured by taking three (3) discs from the equatorial region of 3 fruits from each of the ripening stages and oven-dried at $80^{\circ} \mathrm{C}$ until a constant weight was reached. The dry matter was then calculated as a percentage of fresh disc weight.

Pericarp Thickness (PTK): A high precision digital caliper was used to measure the pericarp thickness $\left(\mathrm{g} / \mathrm{cm}^{2}\right)$ of 3 discs taken at the equatorial region of 3 fruits per cultivar (12 fruits) selected from different blocks.

Membrane Ion Leakage(EL): The membrane ion leakage of fruits was determined by incubating 5 discs (14mm diameter) per cultivar in $20-\mathrm{ml}$ double distilled de-ionized water at 5, 10, 15, 30, and 60 minutes intervals and conductivity measured and expressed as a percentage of total electrolytes. Total electrolyte was also determined by freezing samples overnight after taking all readings (from 5 to 60 minutes). Samples were then thawed, boiled for $15 \mathrm{~min}$, and conductivity measured. Conductivity 
meter (Hanna instruments, made in Portugal) was used to measure membrane ion leakage.

Fruit Firmness(FF): Fruit firmness was determined by feeling how hard or soft the fruit was. The fruits were rated on a scale of $1-5$ with;0 $-1=$ very firm

$$
\begin{aligned}
& 1-2=\text { firm } \\
& 2-3=\text { soft } \\
& 3-4 \text { and above = very soft }
\end{aligned}
$$

Statistical Analysis: All data collected were analyzed to determine variance and interactions between the parameters studied using the Fit Model of JMP Statistical Analysis Software Programme (Sall et al., 2001). Multiple regression analysis was also used to establish association between various quality and shelf life parameters.

\section{RESULTS AND DISCUSSIONS}

Relative Water Loss: Water loss is the principal cause of fruit softening and shriveling (Wilson et al., 1999). The authors further stated that many fruits, vegetables and flowers become shriveled after losing only a small percentage of their original weight due to water loss. There is therefore the need for fresh fruits to have adequate water to be able to prolong the shelf life of the fruit even when they lose some amount of water during storage. 'Rendo' had the lowest water loss even though it was relatively low in weight (Table 1). From the FAO Corporate Document Repository (1986), the rate at which water is lost varies with type of produce and the significant factor in water loss is the ratio of the surface area of the type of plant part to its volume. That is, the greater the surface area in relation to the volume the more rapid water is lost. This might therefore be the reason for 'Cocoa' and 'Power' recording highest in the fruit weight and also in water loss (Table 1).

Sihag and Mentha (1999) made a statement that water loss increases with increasing periods of storage up to 8 days in grape fruits. This might obviously account for 'Power' losing more water at $75 \%, 95 \%$ and $50 \%$ ripening stages after 6 days of storage whereas 'Rendo' recorded the least, which might also be due to its inherent characteristics such as relatively high pericarp thickness (0.59) (Table 1 and Figure 1).

Table 1: Means of fruit fresh weight (FFW), relative water loss (MRWL), relative water content (RWC), fruit firmness (FF), membrane ion leakage (EL), total soluble solids (TSS), pericarp thickness (PTK), and relative dry matter (RDM) of four (4) tomato cultivars after six days storage at room temperature $\left(24^{\circ} \mathrm{C}\right)$

\begin{tabular}{|l|l|l|l|l|l|l|l|l|}
\hline Cultivar & FFW (g) & MRWL (\%) & RWC (\%) & FF (g) & EL (\% el) & TSS (\%Brix) & $\begin{array}{l}\text { PTK } \\
\left(\mathrm{g} / \mathrm{cm}^{2}\right)\end{array}$ & \begin{tabular}{l} 
RDM (\%) \\
\hline COCOA
\end{tabular} \\
\hline POWER & $49.44 \mathrm{a}$ & $0.82 \mathrm{~b}$ & $3.74 \mathrm{a}$ & $2.85 \mathrm{a}$ & $14.51 \mathrm{a}$ & $4.71 \mathrm{a}$ & $0.54 \mathrm{~b}$ & $14.89 \mathrm{a}$ \\
\hline RENDO & $48.50 \mathrm{a}$ & $0.95 \mathrm{a}$ & $3.02 \mathrm{~b}$ & $2.33 \mathrm{~b}$ & $14.18 \mathrm{a}$ & $3.56 \mathrm{~b}$ & $0.64 \mathrm{a}$ & $13.14 \mathrm{~b}$ \\
\hline PETOMECH & $39.34 \mathrm{~b}$ & $0.71 \mathrm{c}$ & $2.91 \mathrm{~b}$ & $1.63 \mathrm{~d}$ & $12.53 \mathrm{~b}$ & $4.38 \mathrm{a}$ & $0.59 \mathrm{~b}$ & $13.65 \mathrm{~b}$ \\
\hline
\end{tabular}

*Values connected by the same letter are not significantly different at $\mathrm{P} \leq 0.01$, according to Tukey -Kramer honestly significant difference. 
Agric. Biol. J. N. Am., 2013, 4(3): 252-259

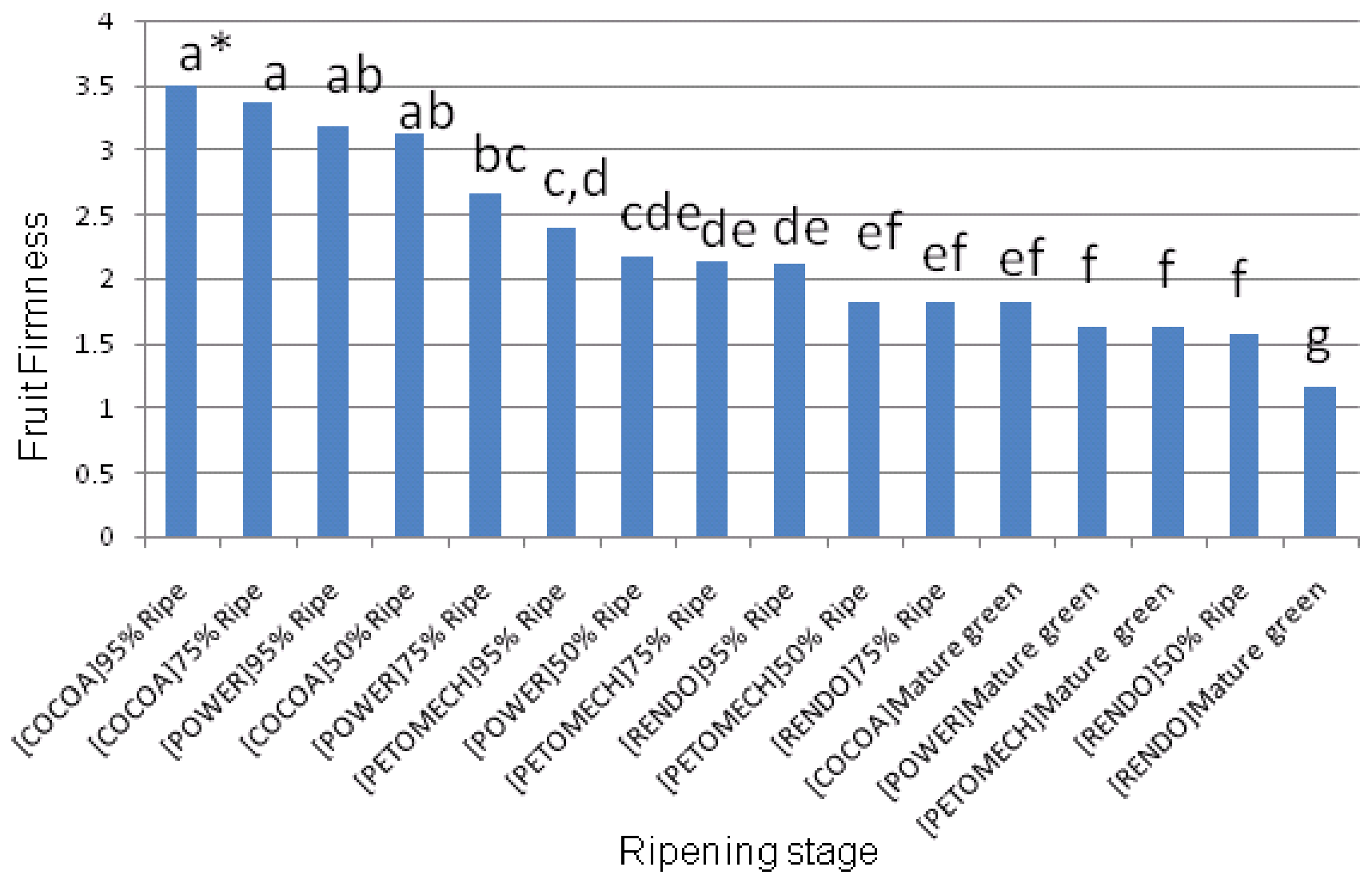

"Bars with the same letter do not differ significantly; at $\mathrm{P} \leq 0.01$ according to Tukey-Kramer honestly significant differ.

Figure 1: The effect of the stage of ripening (mature green, $50 \%$ ripe, $75 \%$ ripe and $95 \%$ ripe) on fruit firmness of four tomato cultivars after six days storage at room temperature $\left(24^{-} \mathrm{C}\right)$

Fruit Firmness: Results of fruit quality evaluation showed that 'Rendo' was significantly firmer than 'Petomech', 'Power', and 'Cocoa' after storage (Table 1). However 'Cocoa' and 'Power' were softer, cracked and more wrinkled than the other two cultivars. Excessive softening which may cause shrinkage as stated by Priya-Sethu et al. (1996) may severely reduce quality and acceptability of the produce. The loss of firmness during ripening leads to a lower quality and higher incidence of mechanical damage during handling and transportation (Hibler and Hardy 1994). Hibler and Hardy (1994) noted that pulp firmness is inversely related to ripening, implying that if ripening progresses, pulp firmness declines which is similar to the present findings of ripening effect of 'Rendo' on firmness. The matured green and $50 \%$ ripe stages of 'Rendo' recorded the highest value whereas 'Cocoa' indicated the least fruit firmness with $95 \%$ and $75 \%$ red ripe fruits (Figure 1 ). Lownds et al. (1994) reported that pronounced decrease in firmness is associated with increase weight loss during prolong storage of pepper. This may most likely be the reason for Cocoa and Power scoring the least firmness which corresponds to their high water loss status. It was observed that, increase in ripening, increases the rate of water or weight loss which results in decreased fruit firmness (Hibler and Hardy, 1994; Lowndset al., 1994).

Membrane Ion Leakage: Cultivars susceptible to high water loss rate also showed very high and positive correlation with membrane ion leakage such as Cocoa (14.51\%) and 'Power' (14.18\%) Tables 1 \& 2 ). The loss of cell membrane integrity is known to cause ion leakage and unrestricted movement of fluids within cellular compartments a condition injurious to fruits (Maalekuuet al., 2005). The authors further stated that membrane ion leakage varied within species or cultivars, being high in pepper cultivars with high water loss rate and low in cultivars with low water loss rate. Similarly the results revealed that, membrane ion leakage varied within cultivars, 
being high in tomato cultivars with high water loss rate ( Cocoa and Power) and low in cultivars with low water loss rate (Rendo and Petomech) (Table 1). These results suggest a strong association between membrane ion leakage and weight loss in the tomato fruits (Table 2) which is in agreement with Walter (1990), who found a relationship between increased water loss and increased membrane ion leakage in cucumber (Cucumi s sativus) fruits stored at $62 \%$ $\mathrm{RH}$. However 'Cocoa' at 95\% ripe, had the highest membrane ion leakage, followed by 'Power' at $50 \%$ and $75 \%$ whereas 'Rendo' (95\% ripe) and 'Petomech' (50\% ripe) recorded the least ion leakage (Figure 2 ).

Table 2: Correlation coefficient values of fruit firmness (FF); pericarp weight (PWT ); relative water content (RWC); total soluble solids (TSS); relative dry matter (RDM); pericarp thickness (PTK); fresh fruit weight (FFW); relative water loss (RWL); and membrane ion leakage (EL) of four tomato cultivars after six days storage at room temperature $\left(24^{\circ} \mathrm{C}\right)$

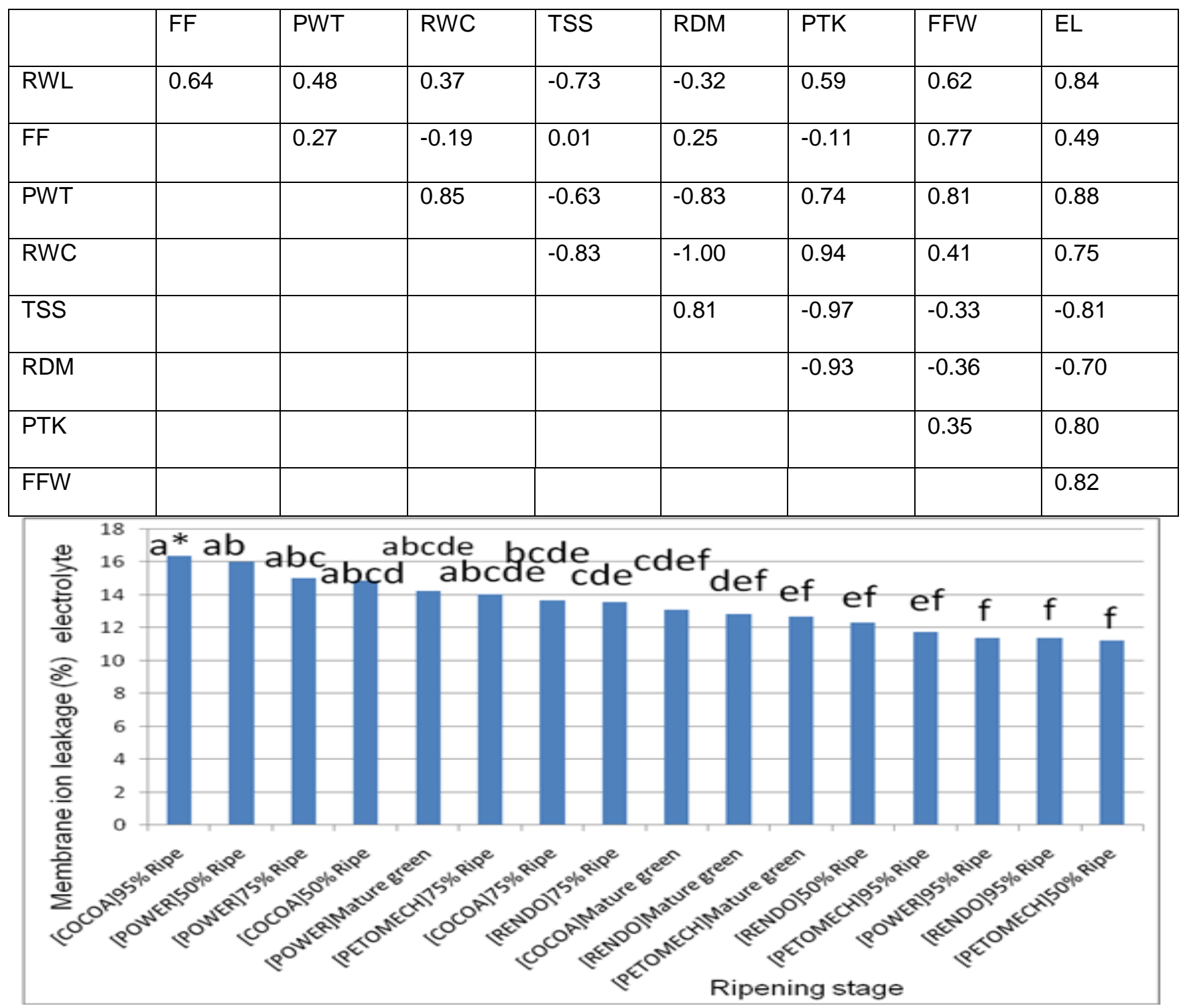

"Bars with the same letter do not differ significantly, at $\mathrm{P} \leq 0.01$ according to Tukey-Kramer honestly significant difference.

Fig 2: The effect of ripening stage on membrane ion leakage (EL) of four tomato cultivars after six days storage at room temperature $\left(24^{-} \mathrm{C}\right)$. 
Total Soluble Solids: Total soluble solids and dry matter are known to increase fruit quality (Loboda and Chuprikova, 1999), which fits in well with consumers demand for high quality produce (ElSaeid et al., 1996). However these two parameters (TSS and membrane ion leakage) do not correlate with external fruit quality and marketing stability during harvesting season (Maalekuu et al., 2004). Power recorded the least TSS with significant difference between Rendo and the other two cultivars (Petomech and Cocoa), (Table 1). The TSS of each cultivar at different ripening stages revealed different total soluble solids (Fig. 3). It is however difficult to obtain a pattern as suggested by Wilson et al. (1999)
- that total soluble solids increase with ripening stage. It is obvious from this experiment (Fig. 3) that tomato of different cultivars exhibit different magnitudes of TSS which therefore agrees with Hibler and Hardy (1994) - that the magnitude of increase of total soluble solids in banana is dependent on cultivar or hybrid. Petomech fruits at matured green recordedthe highest soluble solids, followed by Cocoa (95\% ripe) and 'Petomech' at $50 \%$ ripe in $3^{\text {rd }}$ position. 'Power' however showed the least at its first three ripening stages (Matured green, $50 \%$ and $75 \%$ ), (Figure 3 ). The differences might be attributed to their genetic properties (Emery, 1970), since TSS is known to increase with ripening stages.

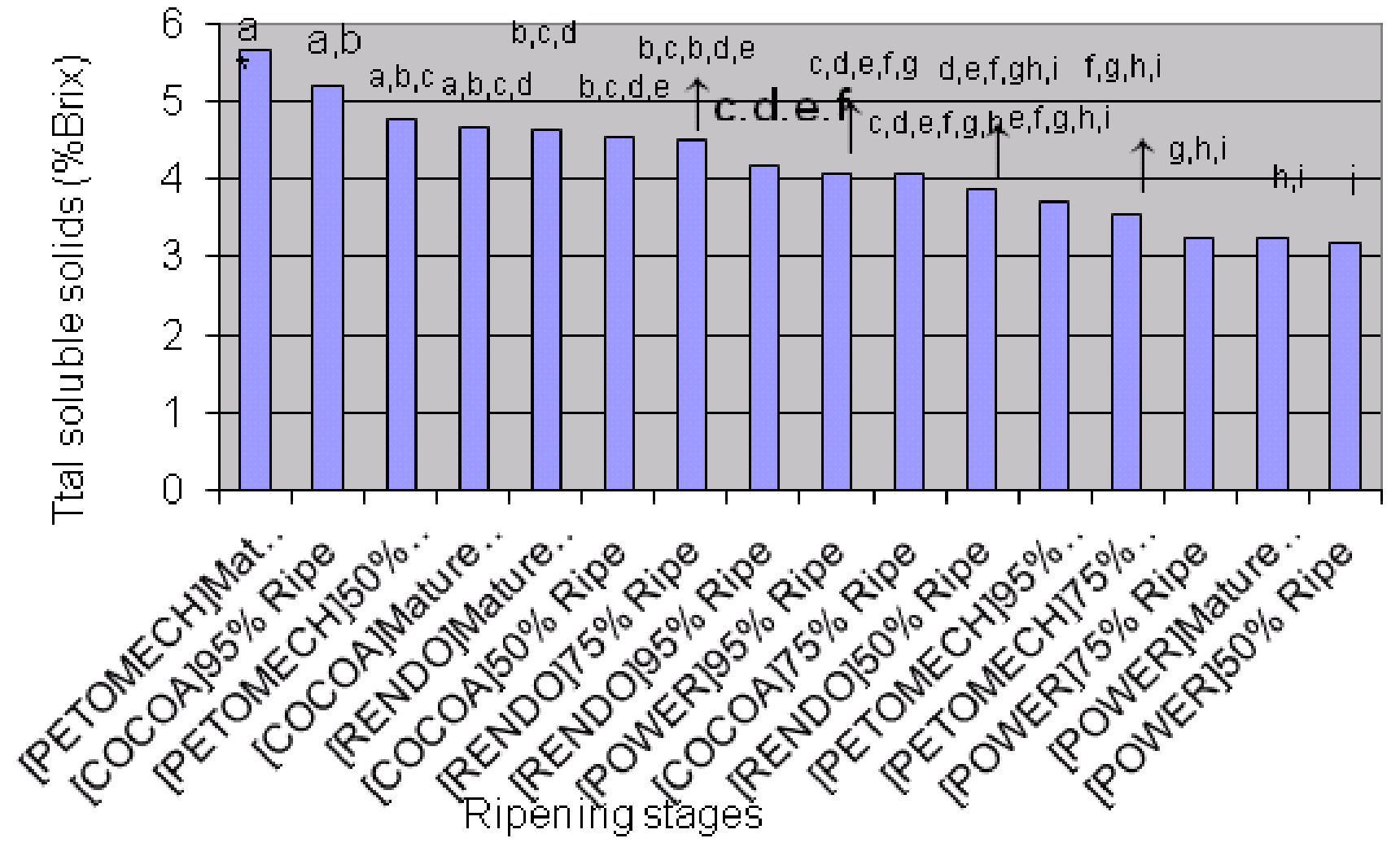

Fig 3: The effect of ripening stage (matured green, $50 \%$ ripe, $75 \%$ ripe and $95 \%$ ripe) on total soluble solids of four tomato cultivars after six days storage at room temperature $\left(24^{\circ} \mathrm{C}\right)$

Pericarp Thickness: Pericarp thickness and epicuticular wax inhibit water loss in fruits (Wills et al., 1998). Cocoa however recorded the least pericarp thickness while Rendo was relatively higher as indicated in (Table 1). Power with the thickest pericarp $\left(0.64 \mathrm{gcm}^{-2}\right)$, also recorded the highest water loss which may be due to its low epicuticular wax content. Moctezuma et al. (2003) reported that tomato fruits with antisense suppression of Betagalactosidase (TBG 6) had a much thicker cuticle and was very prone to fruit surface cracking. It was observed that Power was prone to fruit cracking which could explain the reason for high water loss rate. Harvest effect on pericarp thickness was highest in harvest one with Power, Rendo and Petomech and lowest in harvest two. This indicates that pericarp thickness is not only influenced by cultivar type but also environmental and cultural practices adopted.

Relative Dry Matter: Kader et al. (1987) stated that tomato fruit quality for fresh consumption is determined by firmness and dry matter. Fruits with 
higher dry matter content such as Petomech $(15.14 \%)$ and cocoa (14.89\%) recorded lower pericarp thickness $\left(0.56 \mathrm{gcm}^{-2}\right.$ and $0.54 \mathrm{gcm}^{-2}$ respectively) and lower water content $(84.72 \mathrm{~g}$ and $85.06 \mathrm{~g}$ respectively), (Table 1 ).

According to Opara and Tadesse (2000) respiration results in loss of fruit dry matter and weight. They also stated that dry matter content changes with ripening and fruit colour, which is the main indicator of maturity. From the results obtained, Rendo at $95 \%$ ripe and Power at 50\% recorded the lowest dry matter content whiles Petomech and Rendo at matured green showed the highest. This parameter is therefore an important internal quality attribute of fruit products (Slaughter, 1995) and has resulted in consumer demand for high quality produce- high TSS and dry matter (Maalekuu et al., 2004).

Correlation: Relative water loss correlated highly with fruit firmness (Table 2), indicating that fruits with high firmness lost less weight. According to Lownds et al. (1993, 1994), Mitcham, (1994), loss of fruit firmness increases susceptibility to bruising and decay during shipping and storage and these affect the water loss. Water loss also correlated positively with membrane ion leakage. This explains why fruit with the higher water loss also had higher membrane ion leakage. Relative water loss correlated positively with fruit fresh weight. This implies that the higher the fruit fresh weight the higher the water loss. However relative dry matter showed no correlation with relative water loss. Fruits with high total soluble solids showed high correlation with membrane ion leakage. TSS was inversely associated with pericarp thickness $(-0.97)$. Fruits with thin pericarp however showed higher TSS. This might be attributed to the reason assigned by Wiedemann and Neinhuis (1998) and Kader et al. (1987), that the hydrolysis of starch into soluble sugar corresponds to the rapid increase in soluble solid content of fruit and therefore the loss in pericarp thickness during ripening (softening) results principally from disassembly of the primary cell wall and middle lamella.

High membrane ion leakage was also recorded in fruits with higher fresh weight, inferring that fruits with high amount of water are most probable to leak high amount of ions in their membranes.

\section{CONCLUSION}

Generally Rendo was outstanding in most of the parameters studied during and after storage. However this might be due to its high physical characteristics such as high fruit pericarp thickness, fresh weight and firmness that lead to low membrane ion leakage and water loss. Shelf life begins after harvest, therefore maintaining a low rate of weight loss and softening in tomato fruits after harvest is important for prolong storage and distant markets.

In summary, the results of these studies indicate that Rendo could be grown by farmers even in distant farms that have problems with shelf life due to the length of transportation since it possesses properties which can prolong its shelf life. This will therefore help eliminate additional costs in adopting modified storage methods. In areas where refrigeration is not available such as the local market, such fruits could be stored longer than normal and could also attract better prices as consumers usually go in for fruits with higher firmness.

Basset (1986) stated that, thickness of pericarp affects the shelf life of fruits during storage. In view of this, it would therefore be interesting to characterize further the water loss inhibition properties of pericarp thickness with the aim of developing tools to further enhance this property, and prolong shelf life which will eliminate additional costs in adopting modified storage methods.

\section{REFERENCE}

Atherton J. G. and Rudich, J. (1986). The tomato crop. Chapman and Hall Press pp 260-273.

Basset M. J. (1986).Breeding of vegetable crops. AVI Publishing Company INC. pp 135-165.

El-Saeid, H. M., Imam, R. M. and El-Halim, S. M. A. (1996) The effect of different night temperatures on mophorlogical aspect, yield parametersand endogenous hormones of sweet pepper. Egyptian J. Hortic., 23:145-165.

Emery, J. C. and Munger, H. M. (1970). Effect of inherited differences in growth habit on fruit size and soluble solids in tomato.J. Am.Soc. Hortic.Sci 95:410-412.

FAO Corporate Document Repository (1986), Prevention of post-harvest food losses in fruits, vegetables and root crops, (FAO's Marketing Guide No. 2, Marketing Fruits and Vegetables.)

Giovanucci I. L, Ashcerio A, Rimm E. B, Stampfer M. M, Colditz G. A, Willett W. C, J. (1995).National Cancer Inst. 87:1767.

Hibler, M. and Hardy, D. (1994).Breeding a better banana.IDRC Report 22(1), pp. 16-18

Kader, A. A. ed, (1992). Postharvest Technology of Horticultural Crops. Second edition, Univ. Calif., Div. of Agr and Nat. Resources, Publ. 3311:pp. 296 
Kader, A., Arpaia M.L., Greve, C. (1987). Fruit maturity, ripening and quality relationships.American Society for Horticultural Science.Vol.112. pp 479.

Loboda, B. P. and Chuprikova, O. A. (1999) Anagroecological evaluation of growing media made from rock containing zeolites with regard to greenhouse cultivation of green peppers. Agrokhimiya, 2: $67-72$.

Lownds N. K., Banaras M., and Bosland P. W. (1993) Relationship between post-harvest water loss and physical properties of pepper fruit (Capsicum annum L.).Hort. Science, 28: 1182-1184.

Lownds, N. K., Banaras M., and Bosland P. W. (1994) Postharvest water loss and storage quality of nine pepper (Capsicum) cultivars. J. Amer. Soc. Hort. Sci., 29: 191-193.

Maalekuu, K., Elkind, Y., Tuvia- Alkalai, S., Shalom, Y., Fallik, E. (2005). Characterization of physiological and Biochemical factors associated with post harvest water loss in ripe pepper fruit during storage. Journal of American Society for Hort. Science 130(5), pp. 735741.

Maalekuu, K., Elkind, Y., Tuvia- Alkalai, S., Shalom, Y., Fallik, E. (2004) The influence of harvest season and cultivar type on several quality traits and quality stability of three commercial sweet peppers during the harvest period. Adv. Hort. Sci., 18:21-25.

Messiaen, C.M. (1994). The Tropical Vegetable Garden.The Macmillan Press Ltd. London and Basingstoke. Pp. 20-22.

Mitcham, E. T. and McDonald, R. E. (1994).Journal of American Society of Horticultural Science.117: 919

Moctezuma, E., Smith, D. L. and Gross, K. C. (2003) Antisense suppression of a B-galactosidase gene (TBG6)in tomato increases fruit cracking. J. Expt. Bot. 54: 2025-2033.

Nkansah, G. O; Owusu E. O; Bonsu K. O and Dennis E. A. (2003). The effect of mulch types on growth, yield and fruit quality of tomato (Lycopersiconesculentum Mill.).Ghana Journal of Horticulture. 2: 55-63.

Norman, J. C. (1992). Tropical vegetable production. Macmillan. Press Ltd. UK. Pp 52-67.

Olympio, N. S and Kukuaih S (2002).Preliminery evaluation of post-harvestreponse of Tomato fruits to soil liming with Calcium Hydroxide. Ghana Journal of Horticulture. 1: 102-107.

Opara,, L. U. and Tadesse, T. (2000). Fruit growth characteristics and chronological development of calyx and splitting in pacific rosie apples fruit. Var .J. publications.pp.19-25.

Priya-Sethu, K. M., Prabha T. N. and Tharanathan, R. N. (1996) Post harvest biochemical changes associated with the softening phenomenon in Capsicum annum $L$. fruits. Phytochemistry 42:961-966.

Purseglove J. W. (1991). Tropical crops dicotyledons. Longman, Singapore Publishers pp.495-572

Romain, R. H. (2001). Crop Production in Tropical Africa.Goekint Graphics Nv. Belgium. pp. 467-475.

Sall, J., Lehman A., and Creighton L. (2001).JMP Start Statistics ( $2^{\text {nd }}$ ed.). Duxbury Press, Pacific Grove, Calif.

Sihag, R. P. and P. K.Mentha (1999). Studies on shelf life of perellete grapes as affected by various cushioning materials. Agricultural Science Digest. 19(4): 251-254.

Slaughter, D.C. (1995).Non-destructive determination of internal quality in peaches and nectarines.Transactions of the ASAE. 38: 617-623.

Tindall, N. D; Rice, L. W. and Rice, R. P. (1993).Fruits and vegetable production in Africa. Macmillan Press Ltd. UK. pp 355-358.

Tindall, N. D. (1992).Vegetable in the Tropics.Macmillan. Press Ltd. UK. pp. 355-358.

Walter, W. M., Epley, D. G. and Mefethers. (1990) Effeect of water stress on stored pickling cucumbers. J. Agr. Food Chem. 38:2185-2191.

Wiedemann, P., and C. Neinhuis.(1998). Biomechanics of isolated plant cuticles.BotanicaActa111: 28-34.

Wills, R.B., McGlasson, W.B., Graham, D. and Daryl, J. (1998).Postharvest. An introduction to the physiology and handling of fruit, vegetables and ornamentals. $4^{\text {th }}$ Ed. Hyde Park Press, Adelaide, S. Australia.

Wilson, L. G, Boyette, M. D and Estes E. A. (1999).Postharvest handling and cooling of fresh fruits, vegetables and flowers for small farms. North Carolina Cooperative Extension Services. pp. 17-21. 